tional power of the federal Parliament to act in the field are thrown into sharp contrast with what Australians must deem the unfortunate situation in the United States.

\title{
GUILT BY ASSOCIATION-THREE WORDS IN SEARCH OF A MEANING
}

\section{I}

In those days they shall say no more. The fathers have eaten a sour grape and the children's teeth are set on edge. But every man shall die for his own iniquity; every man that eateth the sour grape, his teeth shall be set on edge. ${ }^{x}$

The Nuremberg trials, the President's Loyalty Order, and the recent efforts to obtain convictions of Communist Party leaders have evoked criticism by lawyers and laymen alike. The brunt of these attacks has been directed at the techniques employed to establish the criminal responsibility of persons affiliated with associations and groups whose activities have been felt to endanger national security. Writers criticizing these efforts have employed a phrase which has recently become an important addition to the popular vocabulary - guilt by association. ${ }^{2}$ The emotional responses evoked by the phrase arise not alone from the highly charged character of the words themselves but also from the fact that they are used to describe highly controversial proceedings. While the term is employed in an increasing variety of situations, few have devoted any serious effort to assign it any clear meaning.

That guilt by association is a concept repugnant to Anglo-American notions of justice is explicable to some extent from the tacit assumption that "it is of the very essence of our deep rooted notions of criminal liability that guilt be personal and individual."'3 The doctrine of personal guilt has no clear historic origin, and unlike other major assumptions of the common law, it has been the subject of little or no inquiry. While British and American experience has displayed some consciousness of class and family discrimination, the absence of any rigid caste structure has permitted the development of a legal system which tends to evaluate rewards and punishments in terms of individual achievement

I Jeremiah 3r: 29-30.

2 For judicial references to guilt by association see Justice Murphy, concurring in Bridges v. Wixon, 326 U.S. I35, I63 (1945); Dunne v. United States, I38 F. 2d I37, I43 (C.C.A. 8th, I943), cert. den. 320 U.S. 790 (r943). For discussions of the doctrine of guilt by association as it relates to special problems see Chafee, Free Speech in the United States 470-84 (I94I); Emerson, Loyalty Among Government Employees, 58 Yale L.J. I, 9I-94 (r948); O'Brian, Loyalty Tests and Guilt by Association, 6r Harv. I. Rev. 592 (I948); Gellhorn, Report on a Report of the House Committee on Un-American Activities, 60 Harv. I. Rev. II93, I217-24 (I947); Constitutionality of the Taft-Hartley Non-Communist Affidavit Provision, $48 \mathrm{Col}$. L. Rev. 253, 26I-63 (I948); Wechsler, The Issues of The Nuremberg Trial, 62 Pol. Sci. Q. II, 2I23 (I947); Guilt By Association, University of Chicago Round Table No. 573 (Mar. I3, I949).

3 Sayre, Criminal Responsibility for Acts of Another, 43 Harv. L. Rev. 659, 7I7 (I930); see Knauer v. United States, 328 U.S. 654, 669 (I946); Kotteakos v. United States, 328 U.S. 750, $77^{2}$ (I946); Schneiderman v. United States, 320 U.S. II8, I36 (I943). 
and delinquency. Contemporary Anglo-American standards of individual responsibility, however, have by no means been universal. The attaching of guilt or responsibility for criminal acts upon the family or clan of the offender is a characteristic of both primitive societies and totalitarian states. ${ }^{4}$ English legal history itself provides examples of murder-fines and blood feuds predicated upon notions of collective guilt or associate responsibility.5 Modern Anglo-American law, however, has for the most part abandoned these early practices in favor of a theory of punishment more consonant with a political and economic pattern of individual freedom. Our legal system and our common sense would be opposed to "making one man pay for another man's wrong, unless he has actually brought the wrong to pass. . . . unless, that is to say, he has induced the immediate wrongdoer to do acts of which the wrongs, or, at least, wrong was the natural consequence under the circumstances known to the defendant."6

If personal guilt is a major premise underlying the criminal law, can it be said that "guilt by association" is a useful term to describe situations which involve departures from personal guilt? In civil actions, it is a well accepted principle that the doctrine of respondeat superior may be used to impose upon the employer responsibility for the negligent acts of his servants committed during the course of employment. It was early decided, however, in the case of Rex v. Buggins that the principal is not answerable criminally for the acts of his agent without the principal's consent, authorization, or knowledge.7 The shifting of the burden of loss to consumers, which is a principal justification for the application of the doctrine of respondeat superior, has no legitimate application to the criminal law. While the doctrine of Rex $v$. Huggins has been generally accepted in this country, several significant exceptions may be noted. To aid effective police enforcement, employers have frequently been held responsible for their agents' violations of public welfare statutes. ${ }^{8}$ Liability in these cases has been imposed despite the employer's ignorance of the alleged offenses or the agent's disregard of contrary instructions.

In close parallel to this rather special extension of criminal liability is a series of cases which hold that a corporation may be held guilty of any crime committed by its human agents within the course of their employment, as tested by the

4 Code of Hammurabi $\$ 230$ (If a builder has by his bad work, caused the death of a son of the owner of the house, the builder's son shall be put to death); Diamond, Primitive Law 277300 (I935).

5 I Maitland, The Laws of Wales-The Kindred and the Blood Feud, in Collected Papers 202-29 (I9II); ibid., The Criminal Liability of the Hundred, at 230-46; I Pollock and Maitland, The History of English Law Before Edward I, § 8, at 678 (2d ed., I899); see City of Chicago v. Sturges, 222 U.S. $3 \mathrm{I}_{3}$ (rgrr) (upholding constitutionality of a statute imposing absolute liability upon a community when private property is injured through mob violence).

${ }^{6}$ Holmes, Agency, 5 Harv. L. Rev. I, I4 (I8gr).

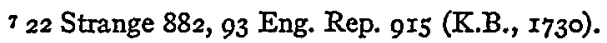

8 See Baty, Vicarious Liability Ig8 (IgI6); Sayre, Public Welfare Offenses, 33 Col. L. Rev. 55 (1933). 
standards applicable to ordinary tort liability. 9 Since a corporation can act only through its agents, and as the shareholders are the persons primarily punished when a corporation is convicted, corporate criminal liability is necessarily vicarious. ${ }^{10}$ The liability of the individual or corporate employer for a minor class of criminal acts committed by agents is, in a sense, a guilt arising from a business association, and a departure from any conventional concept of personal guilt. No one, however, has suggested the use of the term "guilt by association" to describe these well accepted forms of business liability.

A more familiar example of imputing to the accused the criminal act of another-someone with whom he forms a peculiar association-arises in the case of the criminal conspiracy. ${ }^{\mathrm{II}}$ Conspirators may be found guilty not only of the conspiracy itself, but of any of the substantive crimes arising from or in furtherance of the conspiracy. The accused's participation in, knowledge of, or approval of, the specific substantive offense is not prerequisite to his liability for the crimes of a fellow conspirator. A person who associates with others for the purpose of accomplishing some unlawful end, may, under well accepted principles of criminal conspiracy, be held guilty of a crime committed by someone he has never met, at a place which he has never attended. ${ }^{\mathrm{x} 2}$

There is an apparent inconsistency between these three examples of vicarious criminal liability and the doctrine of personal guilt, for ordinarily one is not guilty of a crime unless he is aware of the existence of facts which make his conduct criminal. It is this awareness that is embodied in the concept of mens rea, the "criminal intent," necessary to demonstrate guilt..3 Yet it is not always necessary to prove even this general intent. In a felony murder charge, for example, a man may be guilty without a showing of any intent to commit murder; the fact that he has engaged in a felony dispenses with the need of proving intent to kill. A man tried for statutory rape need not be aware of his victim's age; he takes his chances. Where the accused's conduct is itself unlawful, he is said to assume the risk that that element or manifestation of the activity which he has ignored may in fact exist. .4 $^{4}$

The rationale underlying these examples of extended criminal liability is derived from the doctrine of personal responsibility for the natural consequences of one's acts. The theory of punishment underlying the criminal law is seen to rest upon the principle of causation-men being guilty not only for their own

9 See Egan v. United States, I37 F. 2d 369, 379 (C.C.A. 8th, I943), cert. den. 320 U.S. 788 (1943); Vulcan Last Co. v. State, $x_{94}$ Wis. 636, 643, 217 N.W. 4 r2, 4 r5 (1928).

${ }^{20}$ Lee, Corporate Criminal Liability, 28 Col. L. Rev. I, I3 (I928); Francis, Criminal Responsibility of the Corporation, 18 IIl. I. Rev. 305, 308 (I924).

Ix Pinkerton v. United States, 328 U.S. 640, 646-47 (r945); Vicarious Liability of Co-Conspirators, 56 Yale L.J. 37 I (r946).

I2 See State v. Ritter, I97 N.C. II3, I47 S.E. 733 (I929); 2 Wharton, Criminal Evidence, $\$ 699$ (I935).

${ }_{33}$ Lebitt, The Origin of the Doctrine of Mens Rea, I $_{7}$ Ill. L. Rev. I I7 (I922).

14 United States v. Crimmins, r23 F. 2d 271, 272 (C.C.A. 2d, r94r). 
unlawful acts, but for the forseeable unlawful consequences of their voluntary activities. ${ }^{15}$ The criminal character of private acts stems from the public's interest in the positive or negative consequences of those acts; that is to say, from certain events by which they are followed. ${ }^{16} \mathrm{~A}$ man may therefore be personally guilty of a crime if he performs the forbidden act, if he aids in or abets its commission, or if the specific crime with which he is charged is a probable and natural consequence of his own unlawful conduct. ${ }^{17}$

With this reminder of what Anglo-American lawyers mean when they speak of personal guilt, it is possible to examine the specific circumstances in which the issue of guilt by association has arisen. All so-called cases of guilt by association may be seen to fall analytically into three distinctive categories-attempts to impute criminal liability, efforts to punish persons for the act of associating, and the use of evidence of an individual's associations to establish charges of disloyalty or subversion. Each of these merits separate consideration.

\section{II}

The first situation wherein the issue of guilt by association has arisen is in regard to those circumstances in which the unlawful acts or objectives of an organized society are imputed to an individual who in some manner associates himself with the society. The act of associating is not punished, but it becomes the basis for imposing vicarious criminal liability. It was noted above that criminal responsibility is normally attached to individuals the nature of whose activities causally relates to the substantive offense. Persons who encourage others to commit criminal acts and persons who knowingly set in motion a series of acts which with reasonable forseeability result in a crime, are themselves responsible for the ultimate consequences. The holding of persons criminally liable for the acts of others solely on the basis of their formal membership in a common group goes far beyond the general area of individual responsibility. If, for example, it is a statutory crime to advocate or teach the overthrow of an established government by force and violence, a conviction based solely on an individual's membership in a society dedicated to those purposes would violate both a rule of law and a rule of reason.

The rationale underlying a conviction of this sort would run something as follows:

" $\mathrm{X}$ " organization advocates the commission of an unlawful act.

The Defendant is a member of " $X$ " organization.

Therefore, the Defendant advocates the commission of an unlawful act.

The Supreme Court has refused to attribute to one member the criminal

${ }_{25}$ I Burdick, Law of Crime, $\$$ rI2-I3 (I946); Sayre, Criminal Responsibility for the Acts of Another, 43 Harv. L. Rev. 659, 702-8 (I930).

${ }^{16}$ I Austin, Lectures on Jurisprudence 472 (1869).

${ }_{17}$ This rationale is expressed in the federal Criminal Code, 35 Stat. II52 (rgog), I8 U.S.C.A. $\$ 55^{\circ}$ (I940), which makes liable as a principal: I) the direct actor, or 2) one who aids, abets, counsels, commands, induces, or procures the commission of the criminal act. 
ideas or acts of other affliates in a political party, and has insisted upon proof of the accused's own culpability. ${ }^{18}$ Social and political organizations for the most part reflect a variety of objectives, and "men in adhering to a political party notoriously do not subscribe unqualifiedly to all of its platforms or asserted principles." I9 It is difficult to ascribe character or motive to any amalgamate apart from the personalities and principles of its more dominant members. The amorphous structure of the American mass political party may be less characteristic of the more closely organized, highly disciplined society. The latter may display a more rigid adherence to specified political principles, yet the assignment of a criminal intent to all the members of an organized group results from a spurious identification with a fictitious group personality. ${ }^{20}$ Spurious identification is a process whereby dissimilar objects are given common labels. The label is endowed with particular qualities, and these qualities are in turn attributed to the dissimilar components. ${ }^{2 \pi}$

The spurious identification process is not the only method by which association may become a basis for imputing criminal guilt. A more pernicious form of this technique may appear in criminal conspiracy charges. ${ }^{22}$ The argument in these cases is:

" $\mathrm{X}$ " organization constitutes a criminal conspiracy.23

The Defendant is a member of " $\mathrm{X}$ " organization.

Therefore, the Defendant is a member of a criminal conspiracy.

The faulty logic in this sort of reasoning lies in the indiscriminate use of the term "member." The minor premise uses the term in the sense of formal enrollment on a membership list. The conclusion uses the term as a synonym for participant. The consequences of concluding the defendant's participation in the conspiracy are such as to permit his liability for the acts of co-conspirators. Once this relationship is established, the acts and declarations of his co-conspirators become admissible against him. The reasons for the conspirator's extended liability were discussed above. The concern here is with the use of evidence of association as grounds for establishing participation in a criminal conspiracy.

${ }^{18}$ DeJonge v. Oregon, 299 U.S. 353 (x937). But see Justice Butler, dissenting in Schneiderman v. United States, 320 U.S. I 18, I97 (I943): "A man can be known by the ideas he spreads as well as the company he keeps." In United States v. Tapolcsanyi, 40 F. $2 d 255,257$ (C.C.A. 3d, I930), it was asserted that a defendant's principles "may be proved by showing the principles of the organizations he approved."

19 Schneiderman v. United States, 320 U.S. II8, I36 (I943).

${ }^{20}$ Thouless, Straight and Crooked Thinking, c. 4 (I930); Chase, Spies and Semantics, 13 The Progressive, No. 2, at I9 (Feb., I949).

${ }^{2 x}$ See Strecker v. Kessler, 95 F. 2d 976,977 (C.C.A. 5th, I938); Gellhorn, Report on a Report of the House Committee on Un-American Activities, 60 Harv. L. Rev. II93, I2I7-I8 (1947).

22 O'Brian, Loyalty Tests and Guilt By Association, 6I Harv. L. Rev. 592, 599-605 (I948).

${ }^{23}$ See Proposed House Res. 99, 8oth Cong. Ist Sess. (r947). "Resolved: that Communism be defined and declared to be not a political policy, but is an international conspiracy and an anti-Christian ideology which advocates and practices deceit, confusion, subversion, and the subordination of man to the state. ..." Whitney v. California, 274 U.S. 357, 37 r-72 (r926). 
The secret character of most conspiracies makes proof of their existence by direct evidence extremely diffcult. The existence of a conspiracy may, therefore, be inferred from manifest acts and no proof of an actual agreement is necessary. ${ }^{24}$ To show the defendant's participation in the conspiracy, it has been held unnecessary to prove that the individual defendant was a party to the original agreement or fully aware of all its particulars. ${ }^{25}$ Even with this broad view of conspiratorial participation, the difficulty of obtaining direct proof that the accused was in fact a party to the agreement is evident. For this reason, courts have permitted juries to draw broad inferences of the defendant's agreement and intent from evidence of acts, circumstances, and conduct. ${ }^{26}$ Where a conspiracy is established, a slight quantum of evidence connecting the defendant therewith may be considered "substantial," and if so, sufficient. ${ }^{27}$ The danger which may result from permitting such broad inferences to be drawn is that the defendant "might be found in the net of a conspiracy by reason of the relation of [his] acts to acts of others, the significance of which [he] may not have appreciated."28

In conspiracy charges, evidence of the relations of the parties, the nature of their acquaintance, and the frequency of their being seen together, may be considered by the jury.29 The individual defendant's participation in or knowledge of the conspiracy may not, however, be inferred from his casual and unexplained meetings with other conspirators..$^{30}$ The defendant's affiliation with or membership in a group some of whose members are engaged in a criminal conspiracy may have some probative value. It should not, however, relieve the prosecution of its burden of clearly establishing the accused's participation in the conspiracy. ${ }^{3 x}$

The degree of proof necessary to show participation in a criminal conspiracy may, however, depend upon the nature of the offense charged. The liberality with which the courts have permitted the prosecution of business enterprises for engaging in conspiracies to monopolize or to restrain trade is the most significant example of this relaxation of proof. In attaching liability for violations of the

24 Glaser v. United States, $3^{\text {I5 }}$ U.S. 60 (r942); Madison v. United States, I65 F. 2d 507 (C.C.A. Ioth, 1947).

${ }_{25}$ Coates v. United States, 59 F. 2d $x 73$ (C.C.A. gth, I932); United States v. Wilson, 23 F. 2d II2 (D.C. W.Va., I927).

${ }^{26}$ United States v. Anderson, 45 F. Supp. 943 (D.C. Cal., I942); Oliver v. United States, I2I F. 2d 245 (C.C.A. Ioth, I94I); Parente v. United States, 82 F. $2 d$ 722 (C.C.A. 8th, I936).

${ }_{27}$ McDonald v. United States, 89 F. 2d 128 (C.C.A. 8th, x937); Marx v. United States, 86 F. 2 d 245 (C.C.A. 8th, 1936 ).

${ }^{28}$ Justice Frankfurter, concurring in Von Moltke v. Gillies, 332 U.S. 708,728 (I948).

29 Lance v. State, I66 Ga. I5, I42 S.E. I05 (I928); People v. Childs, I27 Cal. 363,59 Pac. 768 (1899); Reinhold v. State, $\times 30$ Ind. 467 , 30 N.E. 306 (I892); Scott v. State, 30 Ala. 503 (1857).

${ }^{30}$ United States v. Falcone, 3 II U.S. 205, 2 IO (1940); Ellis v. United States, I38 F. 2d 6I2 (C.C.A. 8th, r943).

${ }^{35}$ The Conspiracy Dilemma: Prosecution of Group Crime or Protection of Individual Defendants, 62 Harv. L. Rev. 276 (1948). 
Sherman Act, ${ }^{32}$ the courts have tended to direct their attention to the presence of proscribed activities instead of to the evidence of the accuseds' intent. 33 By engaging in concerted economic activities which operate in fact to restrain trade, the defendants may be charged with having agreed to effect the unlawful results, thereby making proof of a specific intent to restrain trade unnecessary. ${ }^{34}$

III

The second situation in which the issue of guilt by association has arisen is in regard to those circumstances wherein a statute makes the association itself a criminal act. Statutes designed to punish persons for associating with a group of individuals possessed of criminal records or bearing evil reputations have met with little success. An Illinois statute punishing as a vagabond anyone associating with persons bearing or reputed to bear criminal records was held unconstitutional. ${ }^{35}$ While recognizing the necessity for a proper exercise of the state police power, the Illinois Supreme Court noted, "No legislative body in this country possesses the power to choose associates for citizens." ${ }^{36}$ An ordinance of a similar character was invalidated by the Missouri Supreme Court. ${ }^{37}$ A St. Louis ordinance penalizing, as an act of indecency, association on the streets or sidewalks by two or more persons of the opposite sex when one such person shall be of "ill repute" was held void as infringing the rights of personal liberty..$^{8}$ The New York Court of Appeals, while declaring that "mere association of people of ill repute with no intention to breach the peace or commit a crime is too vague a provision to constitute an offense," nevertheless upheld the constitutionality of a statute punishing one "who bears an evil reputation and with an unlawful purpose consorts with thieves and criminals" despite the additional statutory provision to the effect that "consorting with persons of like reputation, thieves or criminals, shall be prima facie evidence that such consorting was for an unlawful purpose." 39

Statutes penalizing membership in or association with unlawful societies fall into several classifications. Membership in an association designated by name has rarely been the subject of punitive legislation. $4^{\circ}$ The absence of such legis-

${ }^{32} 26$ Stat. 209 (I890), I5 U.S.C.A. § I (1946).

33 See Appalachian Coals, Inc. v. United States, 288 U.S. 344 (I933); United States v. Patten, 266 U.S. 525 (1913).

34 United States v. Masonite Corp., 3 I6 U.S. 265 (I942); Interstate Circuit, Inc. v. United States, 306 U.S. 208 (1939).

35 People v. Belcastro, 356 Ill. I44, I90 N.E. $30 x$ (I934).

${ }^{36}$ Ibid., at 303 .

37 City of St. Louis v. Fitz, 53 Mo. 582 (1873); City of St. Louis v. Roch, I 28 Mo. 54I, ${ }_{3}$ S.W. 915 (1895); Ex parte Smith, I35 Mo. 223, 36 S.W. 628 (1896).

${ }^{38}$ Lancaster v. Reed, 207 S.W. 868 (Mo. App., Igxg).

${ }^{39}$ People v. Pieri, 269 N.Y. 3 I5, I99 N.E. 495,498 (r936).

40 Legislation which singles out a designated organization and makes it a crime to be a member thereof may operate as a legislative finding of guilt of a determinate class of persons and 
lative specificity is due probably to the difficulty of effectively enforcing a statute of such character..$^{4}$ The passage of such regulation would stimulate the condemned society to change its name and resort to subterfuge..$^{2} \mathrm{~A}$ statute making past membership in a named society a criminal offense would operate as ex post facto legislation and run into constitutional difficulties. It is for these reasons that British and American statutes punishing affiliation with or membership in unlawful societies have defined these societies in terms of their objectives or methods of operation. 43

American legislation punishing persons who join or associate with unlawful societies is most directly concerned with groups who advocate the overthrow of the government by force and violence.44 The American statutes are of two types. The first is exemplified by the federal law penalizing persons who join "knowing" the purposes of the unlawful organization. 45 In the single instance in which this statute has been tested, the court dismissed the accused's contention that the legislation imposed guilt by association by pointing out that the statute did not include one who had joined while ignorant of the group's unlawful objectives and who remained passive and uninformed. $4^{6}$ The second group of statutes relating to punishment for the act of associating are so phrased as to make any sort of membership unlawful. In the enforcement of this latter type

thus come within the definition of the bill of attainder enunciated in United States v. Lovett, 328 U.S. 303 (1946); see Communist Party of the United States v. Peek, I27 P. 2d 889, 897 (I942).

Proposals designed to outlaw directly the Communist Party have been introduced but have as yet failed to secure passage; see H.R. $2122 \S 2$, 8oth Cong. Ist Sess. (1947); Ill. S.B. I56 $\S 5$ (I949).

As an example of how private groups have adopted the technique of making membership in the Communist party an explicit ground for expulsion see Const., Utility Workers Union of America (CIO), Art. 3, $\$ 5$ (x946); Const., United Cork, Linoleum and Plastic Workers of America (CIO), Art. 9, § I (I946).

4x Letter, L. H. Phillips, professor of political science, Colo. State College of Education, N.Y. Times, $\$ 4$, p. $8 \mathrm{E}$, col. 6 (May II, x947), relating to the unsuccessful Canadian experience with direct "outlawry" legislation.

${ }^{42}$ As an example of how legislatures may seek to avoid this difficulty, see H.R. I884 $\S 2,80$ th Cong. Ist Sess. (I947), which defines the Communist Party as "the political party now known as the Communist Party of the United States, whether or not any change is hereafter made in such name."

${ }^{43}$ Early British legislation in this field provided punishment for any member of an unlawful club or society or any person who directly or indirectly maintains correspondence or intercourse with such a society. 39 Geo. III, c. $79 \S \S 2,8$, 9 (I799); 57 Geo. III, c. I9 § 25 (I8I7). Despite its loose wording and broad coverage, the British legislation has been used only rarely.

${ }_{44}$ Conduct Proscribed as Promoting Violent Overthrow of the Government, 6r Harv. L. Rev. I2I5 (I948); Restraints on American Communist Activities, 96 U. of Pa. L. Rev. $3^{8 I}$ (I948).

${ }^{45} 54$ Stat. $67 x$ (I940), I8 U.S.C.A. \& IO(a)(3) (1940).

${ }_{46}^{6}$ Dunne v. United States, I38 F. 2d I37, I43 (C.C.A. 8th, I943). Twelve leaders of the Communist Party of the United States have been indicted under this act. The trial began on January 17,1949 , and is still in progress. For text of the indictment see N.Y. Times, p. 9, col. 3 (Jan. I7, 1949). 
of statute, a majority of courts have interpreted the legislation so as to require a showing of active membership to sustain a conviction. 47 A few courts have held that membership alone is sufficient..$^{8}$

It has been argued that all statutes imposing liability upon persons who join unlawful organizations represent a legislative effort to establish guilt by association. ${ }^{49}$ Keeping in mind the Anglo-American concept of personal guilt, it is possible to determine whether the cases falling within this category represent new departures from this concept. Without considering the wisdom of enacting "violent overthrow" statutes, or the finding of fact that " $\mathrm{X}$ " organization does or does not fall within the statutory definition, the question which needs to be answered is whether these statutes effect an extension of the area of criminal liability.

Where it is stipulated that the only persons who may be punished are those who associate with knowledge of the group's unlawful objectives, the legislature is in effect restating the requirements for the establishment of a criminal conspiracy. Agreement to effect an unlawful objective is the nub of the criminal conspiracy, and agreement may be evidenced by a showing of voluntary association with knowledge..$^{\circ}$ Punishment for conscious participation in an unlawful enterprise falls well within the area of personal guilt. The possible danger in applying this sort of legislation arises in connection with the evidence problem. If the fact of membership is itself sufficient to establish knowledge, then, of course, the courts would be effectively subverting the principle of liability arising from causation..$^{\text {sx }}$ For the most part, however, the problem of properly proving knowledge in this sort of case is not materially different from that which arises in any case necessitating proof of the accused's knowledge.

Quite a different situation presents itself with regard to those statutes making membership itself a crime. It would seem that statutes of this sort are in effect legislative shortcuts designed to avoid the burden of establishing the defendant's knowledge. If knowledge of the group's unlawful program is made immaterial to the issue of the individual's guilt, then a person who joins an organization with wholly innocent motives may subsequently find himself held liable under the terms of a criminal statute as the result of a court finding that the particular group with which he has affiliated does in fact come within the statutory definition. The legality of the defendant's behavior will be judged retrospective to the court's determination of the quality of the group's behavior. Put to the task of

${ }^{47}$ See Shaw v. State, 76 Okla. Cr. 27x, I34 P. 2d 999 (I943); People v. Lloyd, 304 Ill. 23, 88 , I36 N.E. 505,530 (1922).

${ }^{48}$ State v. Boloff, r38 Ore. 568, 4 P. $2 d 326$ (I93 I); State v. Lowery, I04 Wash. 520, 526, I77 Pac. 355, 356 (rgr8).

${ }^{49}$ See discussion relating to the Nuremberg Trial, Pt. IV infra.

${ }^{50}$ Harno, Intent in Criminal Conspiracy, 89 U. of Pa. L. Rev. 624, 646 (I94I).

sI Chafee points out that the courts in these circumstances have in practice required very little evidence to establish such knowledge. Chafee, Free Speech in the United States, 476-8I (r94r). 
guessing whether in joining a particular group he is exercising the lawful right of free association or committing a punishable offense, the individual is left with a doubt as to' whether his conduct will be labelled gregarious or criminal..$^{52}$ Punishment under these circumstances is objectionable not because the statute imposes some new form of guilt which may be termed "guilt by association," but because this sort of legislation is of necessity vague and uncertain in its application. Its terms fail to inform those who are subject to its sanctions what conduct on their part will render them liable to its penalties. ${ }^{53}$

Statutes making association itself a crime may, as the statutes punishing association with persons of ill repute, offend the constitutional guarantees of individual liberty, or, as the statutes imposing liability on all members of a society advocating an unlawful program, be violative of due process for reasons of vague and uncertain application, but they do not extend the area of personal guilt. They are not usefully described as examples of guilt by association.

\section{IV}

The third situation wherein the issue of guilt by association has arisen is in regard to those circumstances in which evidence of an individual's general associations is used to subject him to public censure or to deny him some right or privilege granted by the laws. Applied in this sense, guilt by association is seldom used in reference to a criminal trial procedure. It is used most frequently to describe the procedures followed by "un-American activities committees" and administrative "loyalty boards." Individuals or groups against whom such evidence is offered are rarely subjected to any criminal punishment (they bear no legal guilt), but the social opprobrium and economic consequences which follow such investigative findings may be sufficiently serious as to be regarded as equivalent to a criminal conviction..$^{54}$

The distinctive feature in each of the cases arising under this category is to be found in the nature of the purpose for which evidence of this sort is introduced. "Loyalty boards" and "un-American activities committees" are designed to ferret out individuals whose activities or sympathies are felt in some way to endanger the "national security." They are not primarily designed to handle

$52 \mathrm{~A}$ judicial finding that a specified organization is devoted to the use of force and violence would not be binding upon subsequent courts and should not operate, therefore, to charge defendants in subsequent cases with knowledge of the group's unlawful activities. There is no reported instance of a criminal proceeding in which the court has taken judicial notice of the unlawful programs of an organized society. In noncriminal proceedings, however, several federal courts seem to have taken judicial notice of the Communist Party's espousal of unlawful doctrines. In re MacKay, 7 I F. Supp. 397 (Ind., I947); United States ex rel. Fortmueller v. Comm'r of Immigration, I4 F. Supp. 484 (N.Y., I936); Murdoch v. Clark, 53 F. 2d I55 (C.C.A. Ist, I93r).

53 Connally v. General Construction Co., 269 U.S. 385, 39I (I925); see Lanzetta v. New Jersey, 306 U.S. 45I (r939); Herndon v. Lowry, 30r U.S. 242, 259 (I937).

54 See Durr, The Loyalty Order's Challenge to the Constitution, 16 Univ. Chi. L. Rev. 298 (1949); Protection from Defamation in Congressional Hearings, 16 Univ. Chi. L. Rev. 544 (I949); Letter, Dean Griswold and Professors Scott, Katz, and Chafee of the Harvard Law School, N.Y. Times, $\$ 4$, p. 8, col. 5 (April r3, r947). 
cases involving violations of any statute relating to crimes against the sovereignty such as espionage, treason, or sedition. Presumably the existing law-enforcement agencies are best equipped to handle the traditional criminal charges.55 The investigating committees are concerned with the "crimes" of "disloyalty," "un-Americanism," and "subversion." What activities or ideas may be included in these terms no one has successfully enumerated. $.5^{6}$ They would seem, however, to be used to describe a deflection from some prevailing standard of mental patriotism. Because of the feeling that finding an individual to be "disloyal" or "subversive" has consequences similar to finding him to be guilty of a criminal offense, it is not unreasonable to expect that no person should be made to suffer the social and economic penalties of an investigative determination unless it is clearly established that he was in fact "disloyal" or "subversive"-that he was personally at "fault."s?

It is not meant here to determine the constitutional objections to imposing sanctions upon persons for their otherwise lawful behavior or speech, or to postulate the dangers inherent in the administration of such programs, but rather to analyze the applications of a much overworked phrase. Assuming that "disloyal" persons should be removed from public employment, and that "subversive" leaders in the ranks of government, business, and labor should be "exposed," what relevance does evidence of an individual's associations and habits bear to the determination of his "disloyalty," "un-Americanism," or "subversion"?

Criminal punishment must be based on more than a mere suspicion of guilt. Evidence of an individual's political habits and organizational activities which may create only a suspicion of "disloyalty" is to this extent similar to evidence of reputation. Neither would seem sufficient evidence upon which to base an adverse finding..$^{8}$ The common law has classed reputation evidence as hearsay and permits its introduction in criminal cases for rebuttal purposes only after the defendant has put his character in issue. ${ }^{99}$ In face of this common-law tradition, any statute which permits the introduction of evidence of reputation to establish the probability of the defendant's guilt or which allows reputation to become prima facie evidence of guilt may be seriously questioned. ${ }^{60}$ The barrier

55 Emerson, Loyalty Among Government Employees, 58 Yale L.J. I, 27-29 (I948).

${ }^{56}$ Ibid., at $36-53$.

57 "The fact that the punishment is inflicted through the instrumentality of an Act specifically cutting off the pay of certain named individuals found guilty of disloyalty, makes it no less galling or effective than if it had been done by an Act which designated the conduct as criminal." United States v. Lovett, 328 U.S. 303 , 3I4 (I946); see Bridges v. Wixon 326 U.S. I35, $x_{3}-64$ (r945).

${ }^{88}$ McFarland v. American Sugar Refining Co., 24I U.S. 79 (rgr6). The Admissibility of Character Evidence in Determining Sentence, 9 Univ. Chi. L. Rev. 7 I5 (I942).

${ }^{59}$ I Wigmore, Evidence $\$ 193$ (I940).

${ }^{60}$ Constitutional Validity of Statute Establishing Proof of Reputation as Prima Facie Evidence of Commission of Crime, 30 Mich. L. Rev. 600 (r932). 
to the use of reputation as evidence for or an element of criminal offenses has not, however, been altogether impenetrable. Appeals based on the admission of evidence of reputation to prove violation of the prohibition laws have been denied ${ }^{6 x}$ Evidence to show a defendant's character as a gambler has been sustained. ${ }^{62}$ Several states have statutes punishing persons who bear criminal reputations when these persons are found prowling around commercial or industrial areas. $^{6_{3}}$ Dean Wigmore has expressed the view that no constitutional principles prevent the enactment of legislation defining bad repute as an element of a crime. ${ }^{6}$

Evidence of political affliations, social contacts, reading habits, and economic persuasion is the sort which is most frequently offered at hearings before the investigating committees. ${ }^{6}$ Evidence of association is offered to establish circumstantial proof of the ultimate issue, "disloyalty," "un-Americanism," etc. Like circumstantial evidence in general, evidence of association is proferred to demonstrate circumstances from which the existence of the principal fact may be reasonably deduced or inferred.$^{66}$ Any particular act of association would, of course, be highly inconclusive in establishing an individual's deviation from any standard of "acceptable ideology," but taken together these isolated instances of social conduct may be sufficiently strong to establish probabilities from which the trier of fact may infer the ultimate issue. Evidence of association may then have a direct probative relation to the individual's personal ideological attachments.

The significant objection to the use of association evidence in investigative hearings, therefore, is not that proof of an individual's associates, habits, and affiliations is irrelevant to the ultimate issue of his personal political orientation. The objection may in reality be directed toward the propriety of the inquiry itself-the attempt to censure non-conformists-the use of such ambiguous charges as "disloyal," "subversive," or "un-American." ${ }^{67}$ If one accepts the view that public security demands that persons attached to certain political theories be denied the opportunity to hold key positions in government, labor, or business, then the objection to the investigative proceedings may be that they base their findings on insufficient evidence, upon evidence which fails to meet the burden of proof necessary to establish beyond a reasonable doubt the accused's deflection from the "accepted ideologies." For once it is conceded that persons

6x Anthony v. Commonwealth, I42 Va. 577, I28 S.E. 633 (r925); State v. Wilson, I5 R.I. I80, I Atl. 4I5 (1885).

62 Thornhill v. State, ${ }_{4}$ Ala. App. 647, 72 So. 297 (Igr6).

$0_{3}$ Commonwealth v. Ellis, 207 Mass. 572, 93 N.E. 823 (IgII); In re McCue, 7 Cal. App. 765, 96 Pac. IIo (1908).

${ }^{4} 4$ Wigmore, Evidence $\$ 1354$, at 719-20 (1940).

65 See examples collected in Emerson, Loyalty Among Government Employees, 58 Yale L.J. x, 67-79 (I948).

${ }^{66} 2$ Wharton, Criminal Evidence $\$ \$ 779-80$ (I935). $\quad{ }_{77}^{6}$ See note 36 supra. 
who have not violated any existing criminal legislation may have sanctions imposed upon them because they adhere to potentially dangerous ideas, any group assigned to determine this issue would of necessity utilize evidence of association.

\section{V}

No court has attempted a judicial interpretation of the phrase "guilt by association," nor has it appeared in any nonlegal dictionary or phrase book. Yet "guilt by association" is rapidly becoming an important addition to the vocabularies of lawyers and non lawyers alike. Far too frequently the statement "this is a case of guilt by association" means nothing more than "this is a case I don't like." While it may be valuable to learn the speaker's attitude toward a particular set of facts, it should not be assumed that the employment of the term provides analytical insight into any legal process. Nor should any author assume that his readers are able to attach a common meaning or significance to the phrase. It has been used to criticize: I) cases wherein the status of association serves as a basis for imputing criminal liability, 2) statutes which seek to punish persons for the act of associating and 3) investigations during which evidence of an individual's social contacts, political affiliations, and habits of conduct are introduced to establish charges of "disloyalty" or "un-Americanism." The importance of distinguishing between the three types of cases to which the phrase is applied proceeds from more than scholastic regard for neat verbal categorization. The problems presented by any one of the categories discussed above arise from essentially distinct considerations, and the indiscriminate application of the phrase "guilt by association" to all three types of cases tends only to obscure the factors which make any particular result an undesirable one.

The point may perhaps be best illustrated by reference to a specific example. Article IX of the Nuremberg Charter provided a procedure for declaring the criminality of the more important organizations in the Nazi hierarchy. ${ }^{68}$ The concept of group criminality was advanced as a derivative of the Anglo-American theory of criminal conspiracy.69 By regarding membership in a criminal group as equivalent to participation in a criminal conspiracy, the association might be used as a basis for imputing to the individual the crime of the group. A defendant might thus be held to the liability of a co-conspirator without any proof of his actual entry into the conspiratorial plan. Article $X$ of the Charter provided for the punishment of individual members of these organizations. Membership alone was recognized as a crime and persons convicted under this provision were made liable to punishments ranging from the deprivation of civil rights to death..$^{70}$ The act of associating was regarded as punishable conduct, yet no regard was given to the question of whether or not the association was itself voluntary.

68 The Nuremberg Charter appears in Trial of War Criminals, No. 2420 (Dep't. State, 1945).

${ }_{69} 2$ Nazi Conspiracy and Aggression I6, I7 (1946).

${ }^{70}$ Allied Control Council Law No. Io, as contained in 15 Dept. of State Bull. 862 (1946). 
Eminent commentators, however, have denied that the Nuremberg experiment imposed guilt by association. ${ }^{7 x}$ The justification for their conclusions may be based upon the actual procedures adopted in the trial stage. The Tribunal specifically declared that membership alone was not enough to sustain an individual conviction and it limited the application of Article $\mathrm{X}$ to those members of the criminal groups who had not been conscripted and who either had personal knowledge of the unlawful character of the group's activities or had personally participated therein..$^{72}$ The burden of producing evidence as to each member's status was shifted to the prosecution and the design of the original Charter was effectively modified.

"Guilt by association" has no single clear meaning. It is not always used as an antithesis to personal guilt, for frequently situations so designated fall well within the concept of individual responsibility. The typical case of so-called guilt by association offends the Anglo-American tradition by permitting the imposition of punishment under vague and uncertain standards, or the utilization of insufficient evidence and false identity. If the cases are to be effectively criticized and corrected, an attempt should be made to identify more accurately their crucial defects.

The legal problems presented by the cases discussed above are in no sense unique. In many respects they have been recurrent throughout Anglo-American history. But having stated reasons for restricting the use of the term "guilt by association," it is not to be inferred that the social problem which the phrase seeks to describe is in any sense less serious or immediate. The one factor which may be said to be common to all so-called cases of guilt by association is that each poses a problem as to the extent to which the state may seek to control organized groups by imposing responsibility on individual participants. How best may it regulate anti-social group conduct without too severely limiting the rights of individual citizens?73

The American legal system like the American political structure was designed to operate in an atmosphere in which individual freedom and private initiative were the dominant principles of social organization. The contemporary development toward collective action expressed through the media of well organized economic, social, and political groups has caused the state increasingly to turn its attention to the anti-social designs of large associations. A political society must be provided with means by which to regulate the forces which fail to observe the rules of permissible conduct. If the offender is a private individual, he is termed an outlaw or criminal and his activities are restrained by enforcement of the criminal law. If violence to existing institutions is threatened by an or-

In Gellhorn, Report on a Report of the House Committee on Un-American Activities, 60 Harv. L. Rev. II93, I223 (I947); Jackson, The Law Under Which Nazi Organizations are Accused of Being Criminal, ig Temple L. Q. 37 I, 378 et seq. (I946).

72 Leventhal, the Nuernberg Verdict, 60 Harv. L. Rev. 857, 899 (1947).

73 See the Conspiracy Dilemma: Prosecution of Group Crime or Protection of Individual Defendants, 62 Harv. L. Rev. 276 (r948). 
ganized group, then presumably the group too should be subject to some form of regulation. Control over organized groups may be effected in either of two ways. Legislation may be enacted to encourage the dissolution of the group by imposing criminal sanctions on persons who organize or join an outlawed society. While this technique may be expedient from the point of view of swift and certain results, when applied to organized social and political societies, it may operate with an indiscriminate and altogether dangerous severity. Corporate action and the propensity to combine is as fully characteristic of modern social and political behavior as of economic. ${ }^{74}$ Although freedom of association is not expressly protected by the Constitution, the right of free speech and other basic civil rights would be seriously jeopardized if individuals were severely restricted in organizing and joining associations to promote their views..$^{75}$

A second, and perhaps more feasible, method by which to effect control over organized societies would be to impose sanctions on members who themselves engage in criminal activity. The area of membership liability should be the same as that outlined by the rules set out in the Federal Criminal Code. ${ }^{76} \mathrm{It}$ would be a serious error, however, to attempt to effect this control by assigning criminality to any fictitious group entity. Persons tried for criminal acts committed through the medium of organized associations should be afforded the safeguards of the traditional criminal trial.

\section{POST-KINSEY: VOLUNTARY SEX RELATIONS AS CRIMINAL OFFENSES}

The recent publication of the Kinsey Report, ${ }^{1}$ the first in a series of studies which will eventually include an entire volume devoted to legal aspects of sex behavior, presents a rare opportunity for re-examining a portion of the criminal law in the light of a factual study of the relevant social behavior. Professor Kinsey and his associates have made a taxonomic investigation of the external sex expression of some 5,300 representative white American males, and the authors' careful methods of sampling ${ }^{2}$ permit, within limits pointed out by responsible critics, ${ }^{3}$ extension of the findings to the whole sampled group.

74 See Wyzanski, The Open Window and the Open Door, 35 Calif. L. Rev. 336 (I947).

${ }^{75}$ Bowe v. Sec'y of the Commonwealth, 320 Mass. 230,69 N.E. 2 d II5, I30 (I946). It would seem appropriate, therefore, to apply the clear-and-present-danger test to legislative restraints on organizing and joining. Shaw v. State, 76 OkJa. Cr. 27I, I34 P. 2 d 999 (I943). In curbing the exercise of constitutionally protected rights, legislation must not be so broad as to comprehend conduct which in all other respects is wholly lawful; see Thornhill v. Alabama, 3 I0 U.S. 88 (1940).

${ }^{76}$ See note 17 supra.

${ }^{1}$ Kinsey, Pomeroy, and Martin, Sexual Behavior in the Human Male (I948).

2 Ibid., at 82-109.

3 Goldstein and Pastore, 26 J. of Psychology 347 (1948); Riley, Some Observations on the Sampling Methods Used in the Report, in Problems of Sexual Behavior 37 (I948). For good 